A R C H I WA，B I B L I O T E K I

I MUZEA KOŚCIELNE 108 (2017)

ROLAND PREJS OFMCap* - LUBLIN

\title{
Z DZIEJÓW PARAFII WNIEBOWZIĘCIA NMP W KRAŚNIKU PO KASACIE KLASZTORU KANONIKÓW REGULARNYCH
} (1864-1970)

Kasata klasztorów w Królestwie Polskim, przeprowadzona nocą z 27 na 28 XI 1864, ma dość obfitą literaturę ${ }^{1}$. Natomiast pokasacyjne dzieje parafii Wniebowzięcia NMP w Kraśniku nie były przedmiotem opracowań publikowanych drukiem. Zresztą dzieje te, obejmujące choćby - jak w niniejszym tekście - okres ponad 100 lat, są zbyt rozległe, by mogły zmieścić się w niewielkim artykule. Dlatego tytuł artykułu został określony „Z dziejów”, zajmiemy się bowiem tylko wybranymi zagadnieniami i to zaledwie zasygnalizowanymi. Na napisanie mono-

* Roland Prejs OFMCap. - prof. dr hab. historii Kościoła; kierownik Katedry Historii Kościoła w Czasach Nowożytnych i Dziejów Teologii; Instytut Historii Kościoła i Patrologii KUL; e-mail: roland@kul.pl

${ }^{1}$ Ważniejsze pozycje: W. Wójcik, Tak zwana reforma klasztorów w 1864 roku na terenie diecezji sandomierskiej, „Archiwa Biblioteki i Muzea Kościelne”, 23 (1971) s. 343-360; A. Petrani, Kasata domów zakonnych $w$ Warszawie w 1864 roku w świetle źródet rosyjskich, „Prawo Kanoniczne”, 15(1972) nr 1-2, s. 267-275; S. Gajewski, Kasata klasztorów w diecezji lubelskiej $w$ roku 1864, „Roczniki Humanistyczne”, 21 (1973) z. 2, s. 351-390; S. Gajewski, Ostatnie klasztory diecezji lubelskiej w XIX wieku, „Roczniki Humanistyczne”, 22 (1974) z. 2, s. 185-214; J. Kałowski, Uprawnienia nad zakonami udzielone biskupom przez Stolice Apostolska po 1864 roku, „Prawo Kanoniczne”, 20 (1977) nr 1-2, s. 137-149; E. Orzechowska, Własność poklasztorna $w$ diecezji sandomierskiej po ukazie z 8 XI 1864 roku, „Roczniki Humanistyczne”, 31 (1983) z. 2, s. 187-212; P.P. Gach, Kasaty zakonów na ziemiach dawnej Rzeczypospolitej i Ślaska 1773-1914, Lublin 1984; A.J. Szteinke, Kościót Świętego Antoniego i klasztor Franciszkanów-Reformatów w Warszawie 1623-1987, Kraków 1990; P.P. Gach, Zakony franciszkańskie na ziemiach dawnej Rzeczypospolitej i Ślaska w latach 1773-1914, w: Zakony franciszkańskie w Polsce, t. 3: Franciszkanie w Polsce XIX wieku, Niepokalanów 1996, s. 11-56; E. Orzechowska, Z działalności patriotycznej bernardynów $w$ Radomiu $w$ dobie powstania styczniowego (1861-1864), w: Zakony franciszkańskie $w$ Polsce, t. 3: Franciszkanie w Polsce XIX wieku, Niepokalanów 1996, s. 149-161; M. Budziarek, Realizacja ukazu cesarskiego z 8 XI 1864 wobec klasztoru kapucynów w Lublinie, w: Zakony franciszkańskie $w$ Polsce, t. 3: Franciszkanie w Polsce XIX wieku, Niepokalanów 1996, s. 163-176; R. Prejs, Zakonnicy franciszkańscy Królestwa Polskiego po kasacie 1864 roku. Dzieje - postawy, Warszawa 2003; R. Prejs, Słownik biograficzny zakonników franciszkańskich Królestwa Polskiego po kasacie 1864 roku, Poznań 2004. 
grafii parafii przyjdzie z pewnością poczekać. Do naszkicowania dziejów tejże parafii w latach 1864-1970 zasadniczo są wystarczające archiwalia przechowywane w Archiwum Archidiecezjalnym w Lublinie, wsparte źródłami drukowanymi, zwłaszcza schematyzmami diecezjalnymi. Autor przyszłej monografii parafii będzie musiał wykorzystać poszerzoną i wszechstronnie zinterpretowaną bazę źródłową, która nie ograniczy się jedynie do archiwaliów proweniencji kościelnej, ale wykorzysta także inne źródła, w szczególności wytworzone przez władze państwowe.

Kasata klasztorów w 1864 roku dotknęła także kraśnicki klasztor kanoników regularnych. Dwaj zakonnicy, ks. Franciszek Albiniak i ks. Felicjan Piątkowski, zostali pozostawieni na miejscu, celem zapewnienia duszpasterskiej obsługi kościoła i parafii ${ }^{2}$, trzech pozostałych, czyli księży Andrzeja Sobańskiego, Szymona Królikowskiego i Ludwika Żytko władze carskie wywiozły do klasztoru paulinów w Częstochowie na Jasnej Górze 3 . Formalnie do klasztoru kraśnickiego należeli także ks. Antoni Boraczyński, ks. Serapion Chmurski, ks. Leopold Czokałło i ks. Wiktor Lebiocki (vel Lebiecki), ale przebywali poza klasztorem i dlatego nie dotknęły ich bezpośrednie działania kasaty: Boraczyński był od 1861 roku wikariuszem w Zakrzówku i starał się o przejście do duchowieństwa diecezjalnego ${ }^{4}$, Chmurski od 1861 roku był kapelanem w Zwierzyńcu na Zamojszczyźnies, Czokałło - jak się wydaje - do klasztoru w Kraśniku należał tylko formalnie, bo nie notują go ówczesne archiwalia'; Lebiocki od 1862 roku był nieformalnym wikariuszem w Dzierzkowicach ${ }^{7}$.

Administrator diecezji lubelskiej, ks. prałat Kazimierz Sosnowski, uznał za niezbędne powierzyć administrację parafii kraśnickiej proboszczowi z niedalekich Popkowic, ks. Leonowi Kaszewskiemu. Czy nie byłoby łatwiej powierzyć tę administrację, choćby czasowo, któremuś z dwóch pozostawionych kanoników? Wydaje się, że to właśnie rodziłoby niejakie trudności. Albiniak i Piątkowski nie odznaczali się szczególną gorliwością, a ich postawa moralna też musiała budzić jakieś zastrzeżenia, mimo, że obaj mieli już pewien staż pracy kapłańskiej, a Piątkowski był nawet jakiś czas wikariuszem parafii w Zakrzówku. Być może właśnie ich postawa kapłańska była powodem, że to ich akurat władze państwowe podczas kasaty klasztoru pozostawiły w Kraśniku ${ }^{8}$ Tymczasem ks. Kaszewski, zajęty

${ }^{2}$ AAL, sygn. 60 IVb 96, k. 56-56v.

${ }^{3}$ E. Niebelski, Kanonicy regularni laterańscy w powstaniu 1863 roku i ich późniejsze losy, w: Przemijanie i trwanie. Kanonicy Regularni Laterańscy w dawnej i wspótczesnej Polsce. Materiały z Międzynarodowej Konferencji zorganizowanej z okazji 600-lecia fundacji opactwa Bożego Ciała $w$ Krakowie, red. K. Łatak, I. Makarczyk, [Kraków 2005], s. 400-402. E. Niebelski pisze wprawdzie na s. 393-394, że został wywieziony także ks. L. Czokałło, ale nie ma go na liście zakonników kraśnickich, którzy znaleźli się w Częstochowie.

${ }^{4}$ AAL, sygn. 60 IIa 107, administrator diecezji lubelskiej 22 VI/4 VII 1865 do Komisji Rządowej Spraw Wewnętrznych i Duchownych.

${ }^{5}$ AAL, sygn. 60 IIa 107, administrator diecezji lubelskiej 22 VI/4 VII 1865 do Komisji Rządowej Spraw Wewnętrznych i Duchownych; E. Niebelski, dz. cyt., s. 400-401.

${ }^{6}$ Niebelski, Kanonicy regularni laterańscy, s. 393-394.

${ }^{7}$ AAL, sygn. IIa 107, administrator diecezji lubelskiej 23 IX 1865 do Komisji Rządowej Spraw Wewnętrznych i Duchownych.

${ }^{8}$ Niebelski, Kanonicy regularni laterańscy, s. 394-395. 
parafią w Popkowicach, do Kraśnika zaledwie mógł od czasu do czasu dojechać, a duszpasterstwo w rzeczywistości sprawowali i tak kanonicy regularni - wspomniani księża Albiniak i Piątkowski ${ }^{9}$. Pomiędzy pozostawionymi zakonnikami a nominalnym proboszczem zaczęło wkrótce dochodzić do jakichś niesnasek, które stały się widoczne dla wiernych. Ludzie oczekiwali też, że kanonicy regularni podtrzymają dawne okazałe nabożeństwa, zarzucali nowemu proboszczowi, że nie dba o służbę Bożą w kościele, że przebywa poza Kraśnikiem, że wreszcie chce usunąć zakonników ${ }^{10}$. Wszystko to na pewno nie sprzyjało sprawowaniu normalnego duszpasterstwa i domagało się, aby ustanowić proboszcza, który będzie rezydował w parafii. Niemniej stan prowizoryczny trwał przez cały 1865 rok, a wydaje się, że ks. Kaszewski rzeczywiście niewiele dbał o parafię w Kraśniku, choć z drugiej strony chyba liczył, że uda mu się opuścić Popkowice, a osiąść w Kraśniku w charakterze pełnoprawnego proboszcza. Być może postrzegał księży Albiniaka i Piątkowskiego jako konkurentów i stąd brały się wzajemne nieporozumienia?

Tymczasem prepozyt kanoników regularnych i dotychczasowy administrator parafii w Kraśniku, ks. Andrzej Sobański, próbował wpłynąć na zmianę sytuacji wytworzonej wskutek kasaty. W marcu 1865 roku zwrócił się do administratora diecezji lubelskiej z prośbą o interwencję u władz państwowych $\mathrm{w}$ sprawie usuniętych kanoników, choć sam nie potrafił jasno określić, czego interwencja miałaby dotyczyć: powrotu zakonników do Kraśnika, czy uzyskania jakiegoś funduszu na utrzymanie dla przebywających w Częstochowie ${ }^{11}$. Gdy prałat Sosnowski zajął wymijające stanowisko ${ }^{12}$, Sobański w kolejnym liście wylał żale zarówno pod adresem rządcy diecezji, jak też aktualnego administratora parafii w Kraśniku, oskarżając obu o przyczynienie się do kasaty kraśnickiego klasztoru ${ }^{13}$. W kolejnych listach domagał się, aby z nim, jako proboszczem, uzgadniać wszelkie zmiany w parafii, wreszcie, by przekazać mu dochody z beneficjum ${ }^{14}$. Prawnie ujmując rzecz, miał rację. Jednakże były to żądania zupełnie nie liczące się z istniejącym stanem rzeczy i świadczące chyba tylko o tym, jak bardzo dawny prepozyt kraśnicki był oderwany od rzeczywistości. Wydaje się też, że ks. Sobański pozostawał w prywatnym kontakcie ze współbraćmi przebywającymi w Kraśniku i od nich miał informacje, co dzieje się w parafii, inaczej trudno wytłumaczyć, że zarzucając ks. Kaszewskiemu - zupełnie niesłusznie - przyczynienie się do kasaty klasztoru, dość szczegółowo wiedział o jego nienajlepszych relacjach z księżmi Albiniakiem i Piątkowskim.

Nominacja proboszcza nastąpiła w styczniu 1866 roku: został nim ks. Kazimierz Wójcicki, który objął parafię 22 lutego $1866^{15}$. Jednocześnie administrator

\footnotetext{
${ }^{9}$ AAL, sygn. $60 \mathrm{IVb} 96$, k. 59-60.

${ }^{10}$ AAL, sygn. $60 \mathrm{IVb} 96, \mathrm{k} .50-51 \mathrm{v}$.

${ }^{11}$ AAL, sygn. 60 IIa 107, Sobański z Częstochowy 30 marca 1865 do administratora diecezji lubelskiej.

${ }^{12}$ AAL, sygn. 60 IIa 107, Sosnowski 3 IV 1865 do przeora paulinów w Częstochowie.

${ }^{13}$ AAL, sygn. 60 IIa 107, Sobański 31 maja 1865 do administratora diecezji lubelskiej.

${ }^{14}$ AAL, sygn. 60 IIa 107, Sobański 1 II 1866 do konsystorza diecezji lubelskiej. Na tymże koncept pisma administratora diecezji lubelskiej 6 II 1866 do dziekana w Urzędowie.

${ }^{15}$ AAL, sygn. $60 \mathrm{IVb} 96$, k. 59-60, 65-65v, 68.
} 
diecezji wydał dla parafii specjalną instrukcję, w której uznał, że kościół poklasztorny jest odtąd kościołem wyłącznie parafialnym, a nie zakonnym, w związku z tym znosi się dawne nabożeństwa zakonne, a w sprawowaniu służby Bożej należy odtąd trzymać się zwyczajów panujących w innych kościołach parafialnych diecezji lubelskiej ${ }^{16}$.

Ks. Kazimierz Wójcicki urodził się 2 marca 1832 w Kurowie. Ukończył gimnazjum w Lublinie, studiował w lubelskim seminarium duchownym, w 1855 roku przyjął święcenia kapłańskie. Do 1860 roku był wikariuszem w Łukowej, następnie krótko w Krasnymstawie, wreszcie w latach 1861-1865 był wikariuszem kolegiaty w Zamościu, gdzie dał się poznać jako gorliwy i roztropny duszpasterz. W 1865 roku miał zostać regensem konsystorza lubelskiego, ale władze państwowe sprzeciwiły się, uważając Wójcickiego za ukrytego sympatyka polskiego ruchu narodowego. Był z tego powodu od 1861 roku pod obserwacją carskiej policji i choć obserwacja niczego nie dała, Wójcicki był na cenzurowanym. Miał wszelkie dane, by stać się godnym i odpowiedzialnym proboszczem, ale władze państwowe zażądały, aby przenieść go z Kraśnika na mniejszą parafię. Po zaledwie kilku miesiącach musiał więc opuścić Kraśnik. Został następnie proboszczem w Mełgwi; w 1870 roku, zachowując probostwo, objął stanowisko rektora seminarium duchownego w Lublinie, z którego jednak zrezygnował w 1886 roku z powodu słabego zdrowia. W 1901 roku zrezygnował też z probostwa w Mełgwi. Zmarł w Lublinie 19 marca $1908^{17}$.

Nowym rządca parafii został 17 grudnia 1866 ks. Apolinary Łopuski, dotychczasowy proboszcz w Biłgoraju ${ }^{18}$. Pochodził z Nowej Wsi koło Węgrowa, gdzie urodził się 22 lipca 1826. Do gimnazjum (1840-1847) uczęszczał w Łukowie i Lublinie, seminarium duchowne (1847-1852) ukończył w Lublinie, przyjmując w 1857 roku święcenia kapłańskie. Początkowo został wikariuszem w Nabrożu, a następnie przez 13 lat był wikariuszem w Szczebrzeszynie i tam podobno został wciągnięty do konspiracji przedpowstaniowej, zostając w 1862 roku skarbnikiem miejscowej struktury powstańczej. Nic wszakże nie wiadomo o jego działalności: może nie zdążył rozwinąć większej aktywności, a może nominacja była wydana „na wyrost”. W każdym razie władze carskie nie uważały go za „niebłagonadiożnogo" i nie zgłaszały protestów, kiedy objął parafię w Kraśniku. Posługiwał w niej do śmierci 13 lutego 1897. Jako proboszcz w Kraśniku naraził się władzom carskim, udzielając tajnie posług duszpasterskich unitom, ale poza upomnieniem inne kary za to go nie spotkały. Uchodził za człowieka uprzejmego i gościnnego, odznaczającego się zacnym charakterem ${ }^{19}$.

Mimo pięknej karty pomocy dla unitów, ks. Łopuski nie był chyba ideałem proboszcza. Nie umiał ułożyć relacji z parafianami, którzy skarżyli się, że proboszcz o kościół zbytnio nie dba, a posługi religijne wypełnia bez większego za-

${ }^{16}$ AAL, sygn. 60 IVb 96, k. 59-60.

${ }^{17}$ E. Niebelski, Stownik lubelskich i podlaskich księży uczestników powstania 1863 roku, Lublin 2011, s. 157-158.

${ }^{18}$ AAL, sygn. $60 \mathrm{IVb} 96, \mathrm{k} .71-72 \mathrm{v}$.

${ }^{19}$ Ś. p. ks. Aleksander [!] Lopuski, „Przegląd Katolicki”, 35 (1897) s. 235; Niebelski, Stownik, s. 87. 
angażowania. Szczególnie przyczyną nieporozumień stał się pożar miasta 12 października 1877, kiedy m.in. spłonęły dachy na kościele i budynkach poklasztornych. Doszło do konfliktu pomiędzy proboszczem a częścią dozoru kościelnego (odpowiednik rady parafialnej, istniejący pod zaborem rosyjskim). Wydaje się, że proboszcz patrzył na remont dachów bardziej praktycznie i z większym znawstwem, dozór zaś chciał dokonać napraw szybko i jak najmniejszym kosztem. Sprawa ciągnęła się przez następne lata i zakończyła dopiero ze śmiercią ks. Łopuskiego $^{20}$. Innym problemem, któremu ks. Łopuski musiał stawić czoła, były dążenia władz państwowych do zajmowania kolejnych części budynku poklasztornego na swoje potrzeby, co ograniczało powierzchnię mieszkalną przeznaczoną dla duchowieństwa i służby kościelnej. Interwencje zarówno proboszcza jak i rządców diecezji przynosiły jednak niewielkie skutki ${ }^{21}$. Jeżeli dodamy do tego, że za czasów kanoników regularnych służbę Bożą w kraśnickiej parafii sprawowało pięciu - siedmiu kapłanów, po kasacie zaś dwóch - proboszcz i wikariusz ${ }^{22}$, będziemy mieli obraz trudności, z jakimi przychodziło się zmierzyć każdemu proboszczowi w Kraśniku: rezydenci bywali w Kraśniku tylko w niektórych latach, przy czym byli to kapłani starsi i raczej niewiele mogli się zaangażować w lokalne duszpasterstwo ${ }^{23}$.

Po śmierci ks. Łopuskiego nowym proboszczem został ks. Władysław Szymoński. Urodzony 13 stycznia 1840 w Szymonie koło Warszawy, w 1857 roku wstąpił do pijarów. W 1863 roku przyjął święcenia kapłańskie i przez przełożonych zakonnych został skierowany do kolegium w Chełmie, gdzie pełnił obowiązki wikariusza miejscowej parafii. Tam zastała go kasata klasztorów. Pozostał w Chełmie jako administrator parafii poklasztornej i w 1866 roku otrzymał sekularyzację, przechodząc w szeregi duchowieństwa diecezji lubelskiej. Władze carskie kilkakrotnie karały go grzywnami za udzielanie posług religijnych unitom przymusowo przepisanym na prawosławie, wreszcie w 1893 roku karnie usunęły z probostwa i osadziły w klasztorze marianów w Mariampolu na Litwie, ponieważ Szymoński nie zaprzestał wspierania unitów. Po powrocie w 1894 roku został wikariuszem w katedrze lubelskiej, w 1896 roku objął probostwo we Włostowicach (dziś dzielnica Puław), a w 1900 roku - w Kraśniku. W Kraśniku pozostawał do 1908 roku, kiedy został mianowany prałatem kapituły kolegiackiej i proboszczem w Zamościu. Tam zmarł 25 lipca $1915^{24}$.

Szymoński przychodził do parafii trudnej w obsłudze duszpasterskiej, liczącej wszak ponad 11.000 wiernych i mającej oprócz kościoła parafialnego kościół filialny w Kraśniku oraz kaplicę w Rzeczycy Księżej. Ponieważ - jak wspomnieliśmy - w parafii bywało tylko dwóch duchownych, proboszcz i wikariusz, nabo-

${ }^{20}$ AAL, sygn. $60 \mathrm{IVb} 96$, k. 93-93 v, 99-105v, 108.

${ }^{21}$ AAL, sygn. $60 \mathrm{IVb} 96, \mathrm{k} .83-83 \mathrm{v}, 85-85 \mathrm{v}, 90-90 \mathrm{v}$.

${ }^{22}$ Catalogus ecclesiarum et cleri dioecesis lublinensis pro anno Domini 1870-1918, [Lublin 1870-1918], passim.

${ }^{23}$ Np. w latach 1897-1900 rezydentem był ks. Leon Popławski, w latach 1902-1905 dominikanin Jozafat Kędrzyński, który zmarł w Kraśniku 29 IV 1905. Catalogus ecclesiarum et cleri dioecesis lublinensis pro anno Domini 1898-1901, [Lublin 1898-1901], passim. Toż 1903-1906, [Lublin 1903-1906], passim.

${ }^{24}$ Niebelski, Stownik, s. 146-147. 
żeństwa we wspomnianym kościele filialnym i kaplicy mogły odbywać się tylko od przypadku do przypadku.

Następcą Szymońskiego został ks. Józef Kobyliński. Urodził się 8 marca 1875 w Przesmykach koło Łosic, w rodzinie odznaczającej się religijną atmosferą domową. Kształcił się w gimnazjum w Siedlcach, a w 1892 roku wstąpił do seminarium duchownego w Lublinie. Studia seminaryjne ukończył w 1897 roku, ale z braku wieku kanonicznego nie mógł przyjąć święceń kapłańskich, dlatego jako diakon został skierowany do Janowa Podlaskiego. Święcenia kapłańskie przyjął 13 marca 1898 z rąk bp. Kazimierza Ruszkiewicza w Warszawie - w Lublinie nie było w tym czasie biskupa. Przed przybyciem do Kraśnika był wikariuszem w Korytnicy Węgrowskiej, a od 1901 roku w Międzyrzecu Podlaskim, skąd po pół roku został usunięty przez władze carskie, które zarzucały mu potajemne wspieranie unitów. Został zatem wikariuszem w katedrze lubelskiej, gdzie dał się poznać jako dobry kaznodzieja i zaangażowany prefekt szkolny. W 1905 roku czasowo zastępował rektora kościoła św. Mikołaja na Czwartku, ale na własną prośbę wrócił do katedry. W 1907 roku został proboszczem w Kraśniku. Wydawałoby się, że nie miał większego doświadczenia duszpasterskiego - przed przybyciem do Kraśnika nie był proboszczem w żadnej mniejszej parafii. W rzeczywistości okazał się sprawnym organizatorem i zaangażowanym duszpasterzem. Wyremontował kościół i budynki parafialne, gorliwie zajął się sprawowaniem służby Bożej, nauczaniem wiary i sprawowaniem sakramentów. Dla wszystkich okazywał się bardzo życzliwy i gotów do pomocy. W 1917 roku założył gimnazjum w Kraśniku i sam objął w nim prefekturę. W 1918 roku opuścił Kraśnik, zamieniając się na parafie z ks. Józefem Scipio del Campo, który odszedł z Siedlec, z parafii św. Stanisława, gdzie był proboszczem. Kobyliński wrócił więc na Podlasie i od bpa Przeździeckiego otrzymał nominację na proboszcza parafii św. Stanisława w Siedlcach, a 20 marca 1919 roku został kanonikiem podlaskiej kapituły katedralnej. Proboszczem w Siedlcach był do 6 lutego 1958, kiedy zrzekł się parafii z uwagi na wiek i stan zdrowia. W 1943 roku awansował w kapitule, zostając kustoszem, a w 1963 roku scholastykiem. Zmarł 20 czerwca 1964 roku w Siedlcach i tam został pochowany ${ }^{25}$.

Kolejny proboszcz w Kraśniku, ks. Józef Scipio del Campo, urodził się 6 IX 1870. Pochodził z włoskiej rodziny od pokoleń osiadłej w Polsce. Do seminarium duchownego w Lublinie wstąpił w 1889 roku, a po trzech latach, w 1892 roku, został wysłany do Akademii Duchownej w Petersburgu. Święcenia kapłańskie przyjął w 1894 roku. Z nieznanych dziś przyczyn w roku święceń kapłańskich opuścił Akademię i został wikariuszem we Włostowicach (dziś dzielnica Puław). Opuszczając Akademię nie uzyskał żadnego stopnia naukowego. Być może przyczyną wycofania się z Petersburga był stan zdrowia i wpływ petersburskiego kli-

${ }^{25}$ Biografia zrekonstruowana na podstawie: Catalogus ecclesiarum et cleri dioecesis lublinensis pro anno Domini 1890-1919, [Lublin 1890-1919], passim; J. Zubka, Ś.p. Ks. Józef Kobyliński, „Wiadomości Diecezjalne Podlaskie”, 34 (1965) s. 71-74; P. Aleksandrowicz, Diecezja siedlecka czyli podlaska. W 150 rocznice erekcji (1818-1968). Przyczynki i materiały do dziejów Diecezji Siedleckiej czyli Podlaskiej, Siedlce 1971, s. 136, 142-143; R. Dmowski, Unitis viribus. Diecezja Podlaska w II Rzeczypospolitej, Warszawa 2013, s. 172-173, 206-208, 212-213. 
matu, ale jeszcze bardziej to, co przejawiło się w jego późniejszym życiu: nie był typem naukowca, lecz działacza. W 1895 roku został wikariuszem w Łukowie, a w 1897 roku - rektorem kościoła pobernardyńskiego w Łukowie, co było niejakim awansem dla młodego, bo liczącego dopiero trzy lata kapłaństwa, księdza. Rektorat kościoła poklasztornego, choć nie był probostwem, był jednak samodzielnym stanowiskiem, do pewnego stopnia od proboszcza niezależnym. W 1898 roku otrzymał równorzędne stanowisko w Lublinie - rektorat kościoła pokarmelickiego św. Józefa. W 1901 roku uzyskał zaocznie stopień naukowy kandydata teologii, najniższy, jaki nadawała Akademia Duchowna w Petersburgu. W 1899 roku został profesorem seminarium duchownego w Lublinie. Jednakże już w 1902 roku objął parafię w Bełżycach, a w 1905 roku przeniósł się na probostwo do Siedlec. W tym mieście zasłużył się przy zbudowaniu nowego kościoła pod wezwaniem Niepokalanego Poczęcia NMP (dzisiejsza katedra). Dał się poznać już wtedy jako gorliwy duszpasterz, a jeszcze bardziej jako człowiek obdarzony zmysłem organizacyjnym i żyłką społecznika. W 1911 roku został mianowany kanonikiem gremialnym kapituły katedralnej w Lublinie. 11 października 1918 został proboszczem w Kraśniku. Wśród duchowieństwa odradzającej się diecezji podlaskiej krążyła plotka, jakoby spodziewał się zostać biskupem podlaskim, a skoro tak się nie stało, zawiedziony opuścił Podlasie i wrócił do macierzystej diecezji lubelskiej. W Kraśniku, oprócz zaangażowań czysto duszpasterskich, aktywnie włączył się w działalność społeczną: był członkiem Rady Stanu Królestwa Polskiego z nominacji Rady Regencyjnej, później zaś, po odzyskaniu przez Polskę niepodległości, należał do Towarzystwa Szkoły Średniej, działał w Lidze Obrony Powietrznej i Przeciwlotniczej, a także w innych organizacjach. W 1923 roku opuścił kanonię gremialną w lubelskiej kapitule katedralnej, został natomiast kanonikiem honorowym, a w 1925 roku otrzymał godność prałata papieskiego. Był ogromnie szanowany przez wiernych w Kraśniku, także z powodu zaangażowania w działalność charytatywną. Po wybuchu II wojny światowej próbował włączyć się w tajne nauczanie, ale postępujący wiek i słabnące zdrowie nie pozwoliły już na większą aktywność na tym polu. Zmarł 26 czerwca 1942 w Kraśniku²6.

Ks. Scipio del Campo planował budowę nowego kościoła w Kraśniku, w części zwanej Kraśnikiem Fabrycznym, gdzie wyrastało osiedle mieszkaniowe w związku z budowaną tam Fabryką Łożysk Tocznych i przewidywaną dalszą rozbudową przemysłu. Kraśnicki proboszcz projektował, że budową miałby się zająć dawny wikariusz w Kraśniku, ks. Józef Gorajek. Wybuch wojny pokrzyżował te projekty, a po jej zakończeniu nie było szans na realizację. Niemniej sprawa budowy nowego kościoła stanie się dla kolejnych proboszczów priorytetowym zadaniem.

${ }^{26}$ Catalogus ecclesiarum et cleri dioecesis lublinensis pro anno Domini 1891-1939, [Lublin 1891-1939], passim; H. Misztal, Scipio del Campo Józef Wojciech, w: Polscy kanoniści, red. J.R. Bar, cz. 2, Warszawa 1981, s. 160-161; J. Wielgus, Nasz Ksiadz Prałat. Ksiadz Józef Scipio del Campo (*1870 + 1942), w: W duchu i prawdzie. Wybrane sylwetki Kościoła lubelskiego (1805-2005), red. H. Misztal, Lublin 2005, s. 198-200. Informację o zawiedzionych nadziejach na biskupstwo podaje R. Dmowski, Unitis viribus, s. 272, trudno jednak ocenić, czy jest ona prawdziwa, czy to tylko plotka podawana $\mathrm{z}$ ust do ust. 
Następcą ks. Józefa Scipio del Campo został ks. Władysław Chruścik (Chróścik $)^{27}$. Pochodził z Turowoli koło Lublina, gdzie urodził się 29 maja 1890. Po ukończeniu seminarium duchownego w Lublinie przyjął święcenia kapłańskie w 1913 roku. Do wybuchu II wojny światowej był prefektem szkół lubelskich. W dniu 9 XI 1939 został aresztowany przez hitlerowców i osadzony w więzieniu na Zamku Lubelskim. Zwolniony 19 marca 1940, początkowo był nieformalnym wikariuszem lub tymczasowym administratorem w parafiach, w których wskutek działań wojennych zabrakło duszpasterzy, a w połowie 1942 roku został proboszczem w Kraśniku. Stanął przed niełatwym zadaniem kierowania parafią w czasie okupacji, a następnie w pierwszych latach po zakończeniu wojny, kiedy trzeba było zająć się odbudową i zorganizowaniem na nowo życia religijnego. Schorowany i doświadczony przeżyciami wojennymi, chciał pracować w mniej absorbującej parafii, dlatego w połowie 1950 roku przeszedł na probostwo do Wojciechowa. Tam zmarł 14 października $1952^{28}$.

W połowie 1950 roku funkcję proboszcza w Kraśniku objął ks. Franciszek Trochonowicz. Pochodził z Podlasia, urodził się 23 listopada 1906. W 1927 roku, po ukończeniu gimnazjum w Białej Podlaskiej wstąpił do seminarium duchownego w Lublinie. Swięcenia kapłańskie przyjął w 1932 roku, a po nich podjął dalsze studia w Lovanium (Belgia), specjalizując się w naukach społecznych i uzyskując magisterium w tej dziedzinie. Po powrocie do Polski został wikariuszem w Zamościu, tam też zastał go wybuch II wojny światowej. 21 czerwca 1940 został aresztowany przez hitlerowców, osadzony początkowo w więzieniu na Zamku Lubelskim, a następnie wywieziony do obozu koncentracyjnego w Sachsenhausen i ostatecznie do Dachau. Po powrocie z obozu w Dachau w czerwcu 1945 roku został dyrektorem Caritas diecezji lubelskiej. Na tym stanowisku został w 1947 roku odznaczony kanonią gremialną kapituły kolegiackiej w Zamościu. Kiedy w 1950 roku władze komunistyczne dokonały zaboru Caritasu, ks. Trochonowicz został proboszczem w Kraśniku. Sprawował tę funkcję do stycznia 1955 roku, kiedy to pod naciskiem władz państwowych został przeniesiony na proboszcza do Janowa Lubelskiego. Tę ostatnią funkcję pełnił do śmierci 19 marca $1969^{29}$.

Nowym proboszczem w Kraśniku został ks. Stanisław Niedźwiński, dotychczasowy proboszcz w Janowie Lubelskim ${ }^{30}$. Oficjalna wersja głosiła, że księża Trochonowicz i Niedźwiński zamienili się parafiami. Rzeczywistość była bardziej skomplikowana. Ks. Trochonowicz wiedział, że władze państwowe od jakiegoś już czasu domagają się, aby opuścił Kraśnik i wywierają pod tym względem naci-

${ }^{27}$ Spis kościołów i duchowieństwa diecezji lubelskiej 1948, Lublin 1948, s. 112.

${ }^{28}$ Z. Goliński, Biskupi i kaptani Lubelszczyzny w szponach Gestapo, Lublin 1946, s. 7; W. Jacewicz, J. Woś, Martyrologium polskiego duchowieństwa rzymskokatolickiego pod okupacja hitlerowska w latach 1939-1945, z. 3, Warszawa 1978, s. 250; Spis kościołów i duchowieństwa diecezji lubelskiej 1955, Lublin 1955, s. 175.

${ }^{29}$ Goliński, Biskupi i kapłani, s. 12; J. Wlazły, Ś. P. Ks. Franciszek Trochonowicz, kanonik kapituły kolegiaty zamojskiej, proboszcz parafii Janów, dziekan dekanatu janowskiego (1906-69), „Wiadomości Diecezjalne Lubelskie”, 43 (1969) s. 260-265; Jacewicz, Woś, Martyrologium polskiego duchowieństwa, s. 277.

${ }^{30}$ Spis kościołów i duchowieństwa diecezji lubelskiej 1955, Lublin 1955, s. 108; Spis kościołów i duchowieństwa diecezji lubelskiej 1966, Lublin 1966, s. 136. 
ski na biskupa, dlatego czuł się zmęczony zaistniałą sytuacją. Zdawał też sobie sprawę, że budowa nowego kościoła w Kraśniku Fabrycznym staje się coraz bardziej paląca, a dopóki on będzie proboszczem, władze państwowe zgody takiej nie udzielą ${ }^{31}$. Biskup lubelski Piotr Kałwa liczył, że ks. Niedźwiński, należący do tzw. księży patriotów (w 1954 roku odznaczony przez władze państwowe Srebrnym Krzyżem Zasługi, stanął później na czele Zarządu Wojewódzkiego Caritas w Lublinie), zgodę taką uzyska o wiele łatwiej ${ }^{32}$. Niestety, władze komunistyczne nawet księdzu - patriocie nie były skłonne pozwolić na budowę kościoła.

Ks. Stanisław Niedźwiński urodził się 5 majja 1904. Święcenia kapłańskie przyjął w 1930 roku. Przed wojną studiował w Innsbrucku. W czasie II wojny światowej był wikariuszem w parafii Rozesłania Apostołów w Chełmie i tam został aresztowany przez hitlerowców 20 września 1939. Zwolniony pomiędzy lutym a czerwcem 1940 roku, wrócił do Chełma i został administratorem parafii Rozesłania Apostołów w Chełmie. Po zakończeniu działań wojennych został 13 października 1946 posłany do parafii Zwiastowania NMP w Tomaszowie Lubelskim, ze zleceniem kontynuowania budowy kościoła Najświętszego Serca Jezusowego i organizowaniem nowej parafii. $\mathrm{Z}$ zadania tego wywiązywał się nadzwyczaj dobrze i budowę doprowadził niemal do końca, jednakże został oskarżony o to, że w czasie wojny współpracował z hitlerowcami, gdy w rzeczywistości, biegle znając język niemiecki, bywał u władz okupacyjnych, by w miarę możliwości wstawiać się za Polakami uwięzionymi, osadzonymi w obozach koncentracyjnych, czy zesłanymi na roboty do Niemiec. 18 lutego 1950 został aresztowany, a następnie skazany na więzienie, które opuścił 23 maja 1953. Bp Piotr Kałwa zamierzał go wtedy mianować proboszczem w Czemiernikach, na co nie zgodziły się władze państwowe, sugerując, aby objął większą placówkę duszpasterską. Chodziło o to, że w czasie pobytu w więzieniu ks. Niedźwiński załamał się, podpisując zobowiązanie do współpracy ze służbami specjalnymi i komunistycznej administracji zależało, aby objął taką placówkę, która umożliwi mu systematyczne przekazywanie informacji o wewnętrznych sprawach Kościoła. Biskup, biorąc pod uwagę, że ks. Niedźwiński był już dziekanem w Chełmie, a następnie w Tomaszowie, uznał, że może być dobrym kandydatem na proboszcza i dziekana w Janowie Lubelskim, na co władze państwowe wyraziły zgodę i ks. Niedźwiński objął tę parafię 1 listopada 1953. Jednakże już na początku 1955 roku przeszedł na probostwo w Kraśniku i sprawował tę funkcję do śmierci. Zmarł 5 kwietnia $1970^{33}$.

${ }^{31}$ P. Tylec, Spór o obsadę personalna parafii Kraśnik i Janów Lubelski w okresie stalinowskim, „Studia Sandomierskie”, 20 (2013) z. 1, s. 187-194.

${ }^{32}$ H. Dominiczak, Organy bezpieczeństwa PRL w walce z Kościołem katolickim 1944-1990 w świetle dokumentów MSW, Warszawa 2000, s. 343-344; Tylec, Spór o obsadę personalna, s. 187194, gdzie dość dokładne omówienie kwestii zmiany proboszcza w Kraśniku w 1954/1955 roku.

${ }^{33}$ Biogram zrekonstruowany na podstawie: Goliński, Biskupi i kaptani, s. 8, 16; Jacewicz, Woś, Martyrologium polskiego duchowieństwa, s. 267; Diecezja lubelska. Informator historyczny $i$ administracyjny, oprac. M. T. Zahajkiewicz, Lublin 1985, s. 411; A. Dudek Problem budownictwa sakralnego w stosunkach państwa z Kościołem rzymskokatolickim $w$ Polsce $w$ latach 1957-1970, „Dzieje Najnowsze”, 27 (1995) z. 1, s. 35-36; W. Kołtun, „,Dobrze jest śpiewać Tobie Panie Boże”. 
Sprawa budowy nowego kościoła w Kraśniku zaczęła się rysować realnie w 1957 roku, kiedy w Polsce nastąpiła pewna liberalizacja polityczna. Ks. Niedźwiński popierał budowę, aczkolwiek ton całej sprawie nadawali wierni świeccy, którzy zarówno powołali komitet budowy jak i wznieśli prowizoryczną kaplicę na placu przeznaczonym pod budowę kościoła. Milicja siłą rozebrała wspomnianą kaplicę, a kiedy w związku z tym doszło do zamieszek, o ich sprowokowanie został oskarżony kraśnicki proboszcz. W rezultacie ks. Niedźwiński został ukarany grzywną, władze państwowe domagały się od bpa Kałwy przeniesienia go do innej parafii, na co jednak biskup stanowczo nie wyraził zgody, a sprawa budowy kościoła musiała ulec zwłoce o wiele lat. Niewiele zatem pomogło zaangażowanie kraśnickiego proboszcza w popieranie władz państwowych ${ }^{34}$.

O ile proboszczowie posługiwali w parafii w Kraśniku przez kilka, kilkanaście, a w wypadku ks. Łopuskiego przez ponad trzydzieści lat, to wikariusze zmieniali się co kilka lat, a niekiedy ich praca w Kraśniku trwała zaledwie rok, stąd trudno ich wszystkich wyliczyć w tym miejscu. Dla porządku musimy natomiast wspomnieć, co się stało z kanonikami regularnymi, którzy po kasacie klasztorów pozostali w Kraśniku. Ks. Franciszek Albiniak w 1866 roku został z decyzji administratora diecezji lubelskiej przeniesiono na wikariusza do Łukawy, potem do Tarnogóry, w 1870 roku do Ratoszyna, a w 1872 roku do Świerżów. Za wspomaganie unitów przepisanych siłą na prawosławie został w 1874 roku karnie przeniesiony do Czernięcina i tam zmarł 8 października $1885^{35}$. Również ks. Felicjan Piątkowski w 1866 roku opuścił Kraśnik, zostając wikariuszem w różnych parafiach diecezji lubelskiej, m.in. w Starym Zamościu i Nieliszu. Zmarł w Nieliszu 8 kwietnia $1884^{36}$.

$$
* * * * *
$$

Dzieje parafii Wniebowzięcia NMP w Kraśniku po kasacie klasztoru kanoników regularnych są ciekawym i wartym dokładniejszego zbadania przypadkiem przekształcania się dawnej parafii zakonnej w diecezjalną, która jednak zachowała w sobie przynajmniej szczątkowe ślady obecności zakonników, zarówno w budynkach sakralnych jak i w pewnych przejawach praktyki duszpasterskiej, choć to ostatnie wymagałoby dokładniejszego zbadania i opisania. W diecezji lubelskiej były dwa podobne przypadki - prowadzone przed 1864 roku przez pijarów parafie w Chełmie i Opolu Lubelskim; inne klasztory, choć były aktywne na polu duszpasterskim, prowadzeniem parafii się nie zajmowały. Dokładniejsze zbadanie dzie-

Chór parafialny przy kościele p.w. Rozestania Św. Apostołów w Chetmie (1918-2011), „Powinność. Pismo kulturalno-społeczne Ziemi Chełmskiej”, 8 (2011) s. 26.

${ }^{34}$ Szczegółowo omawiają tę kwestię m.in.: Dominiczak, Organy bezpieczeństwa, s. 343-344; T. Brzustowski, Studium perfidii. Bezpieka wobec lubelskiego Kościoła katolickiego za czasów biskupa Piotra Katwy w latach 1949-1974, Lublin 2010, s. 152-153.

${ }_{35}$ Catalogus ecclesiarum et cleri dioecesis lublinensis pro anno Domini 1870-1886, [Lublin 1870-1886], passim; E. Niebelski, Kanonicy, s. 400.

${ }^{36}$ Catalogus ecclesiarum et cleri dioecesis lublinensis pro anno Domini 1870-1885, [Lublin 1870-1885], passim. 
jów tej parafii rzuciłoby prawdopodobnie sporo światła na to, jak Kościół w praktycznym duszpasterstwie radził sobie ze wszelkimi ograniczeniami narzuconymi przez carat po powstaniu styczniowym. Natomiast czasy po 1970 roku, zwłaszcza sprawa budowy kościoła w Kraśniku Fabrycznym, należą już do najnowszego okresu dziejów i winny być przedmiotem odrębnego opracowania, które będzie wyraźnie wchodzić w czasy nam współczesne.

słowa kluczowe: kasata zakonu; kanonicy regularni; Kraśnik; parafia Wniebowzięcia Najświętszej Maryi Panny

\section{BIBLIOGRAFIA}

\section{Źródła}

Archiwum Archidiecezji Lubelskiej

sygnatury: $60 \mathrm{IIa} ; 60 \mathrm{IVb}$.

\section{Opracowania}

Aleksandrowicz P., Diecezja siedlecka czyli podlaska. W 150 rocznicę erekcji (1818-1968). Przyczynki i materialy do dziejów Diecezji Siedleckiej czyli Podlaskiej, Siedlce 1971.

Budziarek M., Realizacja ukazu cesarskiego z 8 XI 1864 wobec klasztoru kapucynów $w$ Lublinie, w: Zakony franciszkańskie w Polsce, t. 3: Franciszkanie w Polsce XIX wieku, Niepokalanów 1996, s. 163-176.

Diecezja lubelska. Informator historyczny i administracyjny, oprac. M. T. Zahajkiewicz, Lublin 1985.

Dmowski R., Unitis viribus. Diecezja Podlaska w II Rzeczypospolitej, Warszawa 2013.

Dominiczak H., Organy bezpieczeństwa PRL w walce z Kościotem katolickim 1944-1990 w świetle dokumentów MSW, Warszawa 2000.

Dudek A., Problem budownictwa sakralnego w stosunkach państwa z Kościotem rzymskokatolickim w Polsce w latach 1957-1970, „Dzieje Najnowsze”, 27 (1995) z. 1, s. 35-36.

Gach P.P., Kasaty zakonów na ziemiach dawnej Rzeczypospolitej i Ślaska 1773-1914, Lublin 1984.

Gach P.P., Zakony franciszkańskie na ziemiach dawnej Rzeczypospolitej i Ślaska w latach 1773-1914, w: Zakony franciszkańskie w Polsce, t. 3: Franciszkanie w Polsce XIX wieku, Niepokalanów 1996, s. 11-56.

Gajewski S., Kasata klasztorów w diecezji lubelskiej w roku 1864, „Roczniki Humanistyczne", 21 (1973) z. 2, s. 351-390.

Gajewski S., Ostatnie klasztory diecezji lubelskiej w XIX wieku, „Roczniki Humanistyczne", 22 (1974) z. 2, s. 185-214.

Goliński Z., Biskupi i kapłani Lubelszczyzny w szponach Gestapo, Lublin 1946.

Jacewicz W., Woś J., Martyrologium polskiego duchowieństwa rzymskokatolickiego pod okupacja hitlerowska w latach 1939-1945, z. 3, Warszawa 1978. 
Kałowski J., Uprawnienia nad zakonami udzielone biskupom przez Stolice Apostolska po 1864 roku, „Prawo Kanoniczne”, 20 (1977) nr 1-2, s. 137-149.

Kołtun W., „Dobrze jest śpiewać Tobie Panie Boże”. Chór parafialny przy kościele p.w. Rozestania Św. Apostołów w Chetmie (1918-2011), „Powinność. Pismo kulturalno-społeczne Ziemi Chełmskiej”, 8 (2011) s. 26.

Misztal H., Scipio del Campo Józef Wojciech, w: Polscy kanoniści, red. J. R. Bar, cz. 2, Warszawa 1981.

Niebelski E., Kanonicy regularni laterańscy w powstaniu 1863 roku i ich późniejsze losy, w: Przemijanie $i$ trwanie. Kanonicy Regularni Laterańscy $w$ dawnej $i$ współczesnej Polsce. Materiały z Międzynarodowej Konferencji zorganizowanej z okazji 600-lecia fundacji opactwa Bożego Ciała w Krakowie, red. K. Łatak, I. Makarczyk, [Kraków 2005], s. 385-402.

Niebelski E., Słownik lubelskich i podlaskich księży uczestników powstania 1863 roku, Lublin 2011.

Orzechowska E., Własność poklasztorna $w$ diecezji sandomierskiej po ukazie z 8 XI 1864 roku, „Roczniki Humanistyczne”, 31 (1983) z. 2, s. 187-212.

Orzechowska E., Z działalności patriotycznej bernardynów w Radomiu $w$ dobie powstania styczniowego (1861-1864), w: Zakony franciszkańskie w Polsce, t. 3: Franciszkanie w Polsce XIX wieku, Niepokalanów 1996, s. 149-161.

Petrani A., Kasata domów zakonnych $w$ Warszawie $w 1864$ roku w świetle źródet rosyjskich, „Prawo Kanoniczne”, 15(1972) nr 1-2, s. 267-275.

Prejs R., Słownik biograficzny zakonników franciszkańskich Królestwa Polskiego po kasacie 1864 roku, Poznań 2004.

Prejs R., Zakonnicy franciszkańscy Królestwa Polskiego po kasacie 1864 roku. Dzieje postawy, Warszawa 2003.

Szteinke A. J., Kościót Świętego Antoniego i klasztor Franciszkanów-Reformatów w Warszawie 1623-1987, Kraków 1990.

Tylec P., Spór o obsadę personalna parafii Kraśnik i Janów Lubelski w okresie stalinowskim, „Studia Sandomierskie”, 20 (2013) z. 1, s. 187-194.

Wielgus J., Nasz Ksiądz Prałat. Ksiądz Józef Scipio del Campo (*1870 + 1942), w: Wduchu i prawdzie. Wybrane sylwetki Kościoła lubelskiego (1805-2005), red. H. Misztal, Lublin 2005, s. 198-200.

Wlazły J., Ś. P. Ks. Franciszek Trochonowicz, kanonik kapituly kolegiaty zamojskiej, proboszcz parafii Janów, dziekan dekanatu janowskiego (1906-69), „Wiadomości Diecezjalne Lubelskie", 43 (1969) s. 260-265;

Wójcik W., Tak zwana reforma klasztorów w 1864 roku na terenie diecezji sandomierskiej, „Archiwa Biblioteki i Muzea Kościelne”, 23 (1971) s. 343-360.

Zubka J., Ś.p. Ks. Józef Kobyliński, „Wiadomości Diecezjalne Podlaskie”, 34 (1965) s. 71-74. 


\title{
THE HISTORY OF THE PARISH DEDICATED TO THE ASSUMPTION OF THE BLESSED VIRGIN MARY IN KRAŚNIK AFTER THE DISSOLUTION OF THE MONASTERY OF THE CANONS REGULAR
}

\begin{abstract}
Summary
The history of the parish dedicated to the Assumption of the Blessed Virgin Mary in Kraśnik after the dissolution of the monastery of the Canons Regular is an interesting and worth studying case of the conversion of the former monastic parish to the diocesan one, which, however, retained at least the vestiges of the presence of monks, both in sacred buildings and in certain manifestations of pastoral practice. The latter requires more careful study and description. There were two similar cases in the diocese of Lublin - two Piarist parishes in Chełm and Opole Lubelskie before 1864; other monasteries, though active in the pastoral field, were not involved in running a parish. A more thorough study on the history of this parish could probably shed some light on how the Church performed pastoral work when faced with the restrictions imposed by the Tsar after the January Uprising. The years after 1970, especially the construction of the church in Kraśnik Fabryczny, are part of the most recent period of history and should be the subject of a separate study.
\end{abstract}

Keywords: the dissolution of a religious order; the Canons Regular; Kraśnik; the parish dedicated to the Assumption of the Blessed Virgin Mary 